wholly due to differences in the arrangements of these atoms, all of which move in accordance with strict causal laws, then the possibility of escape begins to appear promising. The new physics has shown conclusively that this atomic conception is mistaken and that, to quote Prof. Whittaker, "determinism does not reign definitely in the physical world".

It is at this point that the philosophy of Sir James Jeans becomes significant. His contention is that there is a new dualism of waves and particles replacing the old dualism of mind and matter. Readers of NatuRe will not require any exposition of this view. Philosophers will wish to ask why exactly Sir James Jeans holds that the 'wave-picture' is more fundamental than the 'particle-picture', and what is the logical basis of his contention that the waves are mental and the particles material, or, as he also puts it, that the wave-picture gives us knowledge and the particle-picture gives us objects. Further, on what grounds does he contend that the waves control the particles; hence that mind controls objects ?

In claiming that the wave-picture is mental, Sir James Jeans seems to have been influenced by three considerations : (1) that the geometrical representation of the waves is more complicated than the geometrical representation required by classical physics; (2) that wave mechanics is a mental construct whereas particle mechanics either is not a mental construct, or at least is not a mental construct in the same sense; (3) that since the waves are waves of knowledge, the determinism involved in the wavepicture originates in part at least in our own minds. It is not clear whether Sir James Jeans considers that (2) follows from (1), but it seems that he must have done so. There is not, in my opinion, any good reason for this contention. Wave mechanics is just as much or just as little a construct as particle mechanics. Hence, if idealistic conclusions are to be drawn from the new physics, they could just as suitably be drawn from classical physics; in fact, they cannot suitably be drawn from either. (3) would appear to be jointly entailed by (1) and (2). Nothing in the discussion or in Sir James Jeans's book shows clearly what exactly are his views with regard to the nature of mathematics. At times he seems to suppose that a mathematical statement is a statement about something mental; at other times he suggests that "God made the mathematics and man made the rest" (in physics). However we interpret this cryptic utterance, it does not seem likely to support the conclusion that objective idealism is in the main correct.

Plain men, especially during the last two centuries, have been apt to take their philosophy from science, meekly accepting whatever scientific men tell them to believe, and thus they are led to deny the plain facts of their own experience if eminent men of science exhort them to do so. It is odd how easily plain men and scientific men alike forget the nature of the abstractions within which experimental science is carried on. Although plain men find difficulty in recognizing themselves as 'cogs in a machine', they see that, if the universe is a great machine, they must indeed be nothing better than cogs. They forget that physics is concerned with certain features in the universe, to the entire exclusion of other features. Accordingly, the rejection of the machineimage is hailed with delight as freeing us from the 'prison-house'. All this is very understandable, but completely without logical foundation. If this be correct, the bearing of the new physics upon the problems raised by Sir James Jeans is psychological; it enables him, and others, to feel differently about the position of men in the physical universe. It has, however, no bearing at all upon the question whether metaphysical materialism is false, or whether the assertion that metaphysical materialism is true or false is itself a statement without assignable meaning.

It may further be urged that, even if the new physics destroyed the basis of the nineteenth century denial of human freedom, there would still remain a greater obstacle to overcome, namely, the part played by man's glandular structure upon his activities. This contention, it may be noted, was not favourably received by the physicists.

\section{BREAST AND BOTTLE FEEDING}

AOUT half the babies born in Great Britain nowa. A days are put on the bottle between the third and sixth months after birth ; the proportion is increasing, but in spite of this the health of babies is undoubtedly improving. It is inevitable that a discussion such as that of the Nutrition Society on May 22 about nutrition in infancy should continually suggest the question : Is there any serious objection to stopping breast feeding after the first few months?

It is easy to suppose that, through thousands of years of selection, a mechanism has evolved that will provide the baby with ideal food, if the mother is supplied with the necessary materials in her own food. But evolution cannot anticipate changes in environment. Piglets kept in a bare sty become seriously anæmic in a few weeks; the sow's milk does not supply them with the iron they need, how. ever much she may be taking'. In their natural state the piglets would pick up enough by rooting in the earth ; in the sty they must be given iron in some form. Man takes his women and babies into equally unnatural environments which may impose demands that the mother's milk will not cover. The amount of vitamin $D$ that is ample for a naked baby in a sunny climate may be wholly insufficient for a baby screened from ultra-violet light by clouds, smoke, house and clothes. It is possible that artificial milk might be prepared that would meet a modern baby's needs better than any human milk.

The disastrous results of artificial feeding in the past were due to dirt and infection with pathogenic bacteria. Milk supplies were filthy; bottles were not clean, often because they were so shaped that it was not possible to clean them; the baby drank an infusion of bacteria, dead or alive. Even if the bacteria were not pathogenic they did not agree with baby. In the last twenty years milk has become cleaner; much that is now supplied to cities is pasteurized; the pattern of bottles has improved and mothers have learned how to use them; house-flies have almost vanished with the horse from cities. These changes have taken away most of the terrors of bottle feeding and of the first few months after weaning. Nine years ago, Grulee ${ }^{2}$ published figures to show that the deathrate of bottle-fed infants was nearly ten times as high as that of the breast-fed. But that was more than nine years ago and, as was pointed out at the Nutrition Society's meeting, Grulee made his investigations among the slum population of Chicago. The "slum population of Chicago" may not be so bad as it sounds, 
for Chicago had a remarkably low infant mortality. rate. Also the milk used was liquid milk; dried milk would have been safer. In this instance the conditions and method of artificial feeding were at fault. With improvement of social conditions and of methods many of the objections to bottle feeding disappear.

There remain the differences in the composition of human and cow's milk. Cow's milk contains less vitamin $\mathrm{C}$ and, if diluted, less $\mathrm{A}$ and $\mathrm{D}$. However, some of the worst cases of rickets that are seen nowadays are among breast-fed babies. Both breast- and bottle-fed babies can now get fruit juices and cod liver oil that supply more of these vitamins than they could get from their mother's milk; so there can be no objection to artificial feeding on this score. Even if diluted, cow's milk supplies more riboflavin than does human milk. But calves grow faster than babies; cow's milk is more a growth and less a maintenance ration than human milk; it contains a higher ratio of protein to calories. Also the protein of cow's milk is mainly casein, while two thirds of that of human milk is lactalbumin. In the past, stress has been laid on differences in the amounts and physical properties of these proteins. Cow's milk has been diluted to reduce the protein concentration; cream.and sugar have been added to keep up the caloric value; citrate also might be added to prevent clotting. But it is doubtful whether the baby is interested in physical properties; it was the bacteria, not the clots, of cow's milk that its stomach resented. After digestion, proteins are equivalent to mixtures of amino acids. Human milk and cow's milk, diluted to the same protein concentration, differ significantly in the amounts of certain of the amino-acids that they supply. This difference in proportion may affect the synthesis of proteins in the rapidly growing organism. Jeans ${ }^{3}$, on the basis of the studies of Catherwood and Stearns ${ }^{4}$, considers that babies that are given cow's milk in quantity sufficient to cause a high nitrogen retention have a larger muscle mass than breast-fed babies; although the 1 breast-fed babies appear to be at no disadvantage owing to their lesser amount of muscle. If an artificially fed baby retains no more nitrogen than a breast-fed baby, its motor development is less good. The quality of the muscle seems to depend on the aminoacids of the milk. The evidence is not conclusive; but these studies suggtest more sensitive tests of the biological value of proteins than are afforded by measurements of nitrogen retention and gain of weight. Further studies might be made on other animals or on identical twins.

A point that was stressed at the meeting was the importance of giving a baby enough food. Here artificial feeding has the advantage; for whereas human milk varies widely in composition and amount, cow's milk has a relatively constant composition, the amount given can be measured and can be increased if necessary. Forty years ago, when breast feeding was more common, one of the standard jokes was that of the baby that cried at night. The joke is now unfashionable; may it not have lost its appeal because mothers who cannot satisfy their babies now give them a bottle and have a quiet night?

It is usual to ascribe the adoption of bottle feeding to selfishness and laziness. But breast feeding is far less troublesome even than careless bottle feeding. The investigations made in Birmingham by the British Pædiatric Association showed that only 11 per cent of women gave up breast feeding owing to going to work. The most common reason given for stopping breast feeding is inability to satisfy the baby. This takes us back to the subject of the previous discussion at the Nutrition Society on "Nutrition in Pregnancy". The Toronto workers found that 86 per cent of well-fed mothers, but only 59 per cent of those on a poor diet, were suckling their babies six weeks after delivery. The ability to feed the baby well may be one of the best criteria of adequacy of the mother's food. After delivery the involuntary sacrifice of the mother to the baby is less complete than before; the milk begins to deteriorate before the deficiency of the diet becomes extreme. Yet, the demands on the mother are heavy; Ellison and Moore ${ }^{5}$ have estimated that the total drain of vitamin A during nine months lactation amounts to 300,000 international units. The average figures given by Dr. Kon imply a daily loss of some 1,000 units of vitamin A and, in winter and spring, $17 \mathrm{mgm}$. of ascorbic acid per day-a considerable fraction of the vitamin A and more than half the ascorbic acid provided by the day's food. The milk supplies some 400 or 500 calories per day. If the mothers continue on a diet no better than those of pregnant women which were collected by McCance, Widdowson and Verdoe-Roe', it must be almost impossible for them to continue, day after day, to spare so many calories. The fashion of disparaging and discouraging the consumption of starchy foods, which must provide the bulk of the calories of the food of all but the wealthy, may have made nursing more difficult. It is not surprising that many mothers, voluntarily or involuntarily, fail to keep up this heavy drain on their own nutrition. Prof. Spence fears that this early termination of the natural reproductive cycle might, in the end, have disastrous results. But we have already interfered profoundly with the natural course of reproduction. It may be that earlier departures from Nature contribute to lack of ability or will to suckle babies for more than three months.

Undoubtedly, when clean cow's milk cannot be got, when housing is inconvenient and insanitary or the mother careless or stupid, bottle feeding is dangerous. Without definite evidence that the welfare of baby or mother suffer from artificial feeding, using proper methods and under suitable conditions, the choice must be left to the mother; the duty of public authorities is to recommend the proper methods and see that the conditions are favourable, particularly that the cow's milk is clean. If breast feeding has advantages over bottle feeding, however done, these advantages should be explained by people who seem to the mothers to understand their outlook and difficulties-as Prof. Spence said, not men and childless women; and again conditions must be favourable for the secretion of a good supply of milk. In either case the first essential is to provide a favourable environment- to get rid of slum housing and slum food.

Dr. Magee of the Ministry of Health could claim that a great advance had been made in this direction during the war years. Little can be done, for the present, to improve housing, but the system of food control, the national milk scheme and the provision of cod liver oil have improved the diet of pregnant and nursing women. The poorest can now get, free, more milk than was drunk by any but a few of the richest mothers whose diets were studied in $1937^{\circ}$. Dr. Magee's tone contrasted happily with that of a chief medical officer to the Ministry of Health ten 
years ago: "It will be realized that with an infantile mortality-rate of 64 per thousand no spectacular improvement can be expected"". In 1942, the infantile mortality-rate in England and Wales fell to 49-lower than in any year before. This in the third year of a major war, with a rising birth-rate, is not merely spectacular; it is an achievement without parallel in history. The newer knowledge of nutrition has been applied and is justified by the results. Dr. Magee justly gave the credit to those who, brick by brick, have built up this modern knowledge. The first part of this meeting may have seemed a tedious fussing about details ; but on these details policy must be based. Much remains to be done, particularly on this question of the relation of breast feeding to the nutrition of the mother.

The national milk scheme and provision of vitamin preparations are not isolated benefits to a small section of the people. With the provision of milk in schools and school meals, they are outstanding steps in the general policy of food control which aims at ensuring food according to physiological needs; they may be the beginnings of a future world policy. It seems that the Food Conference at Hot Springs will not descend to bargains to limit production similar to the wheat and sugar schemes of the past, but will fulfil its promise that the peoples of the world will work together to increase production and adjust distribution to abolish want. If so, our achievement in the midst of this War may stand as a record for all time; not because the mortality of infants, breastor bottle-fed, will not fall far below 49 per thousand, but because a major cause of war will be no more.

1 Fost, A. S., and Thomas, S. Y., J. Min, Agric., 45, 452 (1938)

${ }^{2}$ Grulee, C. G., et al., Trans. Sect. Poediatr. Amer. Med. Ass. (1934).

${ }^{3}$ Jeans, P. C., J. Amer. Med. Assoc., 120, 913 (1942).

- Catherwood, R., and Stearns, J., J. Biol. Chem., 119, 201 (1937).

Ellison, J. B., and Moore, T., Biochem. J., 31, 165 (1937).

-McCance, R. A., Widdowson, E. M., and Verdoe-Roe, C. M., J. Hyg. 38, 597 (1938).

- Annual Report of the Chief Medical Officer of the Ministry of Health for the year 1933, p. 9 .

\section{INDIA'S MINERAL RESOURCES}

\section{By SIR LEWIS FERMOR, O.B.E., F.R.S.}

IKE the British Association, the Indian Science 1 Congress Association meets annually, moving from one important centre to another ; this year the Association met in Calcutta for its thirtieth session. Mr. D. N. Wadia, owing to unforeseen circumstances, created a record by holding the office of general president for a second term. His address as general president during the first of these years was concerned chiefly with the geological origins of India (see Nature, December 19, 1942, p. 725). His second address (see NATURE, May 15, p. 548) dealt with more general matters, only touching on the mineral resources of India. The president of the Section of Geology and Geography, however, Dr. J. A. Dunn, of the Geological Survey of India, gave an address on "Suggestions for the Future Development of India's Mineral Resources" (Proc. 30th Ind. Sci. Cong., Part II, Section IV, pp. 1-22 ; 1943). This is a subject of interest to all who have been concerned with Indian minerals, and one that has, therefore, been discussed previously on numerous occasions. Dr. Dunn has, however, devoted so much of his career in India to the survey and study in the field, as well as in the laboratory, of several of India's principal minerals, that his views must be of value.
Any suggestions for the future development of the mineral resources of a country must be preceded by a statistical stocktaking. The fog of war has, how. ever, descended upon India's statistics of mineral production, the latest published review being that for 1938. This withholding of statistics is in contrast to the practice during the War of 1914-18, when the usual reviews were published annually. The necessity for the present statistical secrecy seems doubtful. Dr. Dunn has met the situation, in what will be to some the most interesting part of his address, with a table showing the relative pre-war mineral production of India and of the principal nations. This table shows the relative production of fifty-four metal and mineral substances by India, the British Empire, the United States, the U.S.S.R., France, Germany, Italy and Japan. The production is not shown by actual figures, but by symbols indicating degree of excess, sufficiency or deficiency, the terms used referring, of course, to a country's output compared with its internal needs, excess justifying export, and deficiency causing import.

According to this table, India has world control in mica, monazite and titanium (ilmenite) ; a large excess of chromite, kyanite and sillimanite, and manganese ore; an excess of beryllium ore, columbite-tantalite, gold and magnesite; and a sufficiency of barium, bauxite, coal, felspar, fuller's earth and bentonite, graphite, gypsum, iron ore, salt, talc and tungsten; whereas supplies of all other minerals are deficient or negligible. Although all would not apply these labels as used by Dr. Dunn, they give an idea of India's position with reference to the world's mineral supplies, and in particular show which minerals she can afford to export, which she needs for internal use, and which she must import if she is to attain and maintain a balanced industrial economy.

The one mineral of which the classification might be altered is gold, in view of the fact that over a long period of years India was a sink for gold obtained mainly by import; and as the Indian output of new gold (from the Kolar goldfield) is a small one, such exports of gold as have taken place since Britain and India left the gold standard have been mainly from hoards of gold previously imported.

Deductions to be drawn from statistics of mineral production, exports and imports, concerning the metal requirements of industrialized countries, are liable to be vitiated, at least partially, by the increasing part that scrap metal plays in modern industry, adequate statistics of which are not pub. lished by any country except the United States of America. Dr. Dunn does not refer to this problem, probably because it has not yet arisen to any major degree for India, which has not long become one of the industrially developed nations. The above reference to gold shows that hoards of precious metals such as gold and silver-although not to be regarded as in any sense a form of scrap-play a similar part. to accumulations of scrap metal in tending to vitiate deductions concerning the mineral economy of a country based on the study of mineral statistics that do not take account of the existence of accumulated stocks of metals, either as such or in the form of scrap metal available for return to industry.

Dr. Dunn next discusses the distribution of minerals in India, a country that illustrates in miniature the world's unequal distribution of useful minerals. For in India 40 per cent of the total mineral output comes from one province, Bihar, with its large 